\title{
CORPORATE ENVIRONMENTAL SUSTAINABILITY - A KEY FIGURE-BASED APPROACH
}

\author{
Sabrina Stern ${ }^{1}$, Sven Steck $^{2}$ and Stefan Waitzinger ${ }^{3}$ \\ ${ }^{1}$ Department Economie, Hochschule für Technik, Wirtschaft und Gestaltung, Konstanz, \\ Germany and Management Consultant at P3 automotive GmbH, Stuttgart, Germany \\ ${ }^{2}$ Managing Partner at P3 automotive GmbH, Stuttgart, Germany \\ ${ }^{3}$ Professor at Department Economie, Hochschule für Technik, Wirtschaft und Gestaltung, \\ Konstanz, Germany
}

\begin{abstract}
This paper describes the rationale and the development of a structured digital approach for measuring corporate environmental sustainability using performance metrics.

It is impossible to imagine today's age without the preservation of our environment, not even in the corporate environment. Currently, sustainability is mostly only rudimentarily considered in companies, mostly only with written down phrases on the website. This will no longer be sufficient in the future, which is why companies should record sustainability on a numerical basis. Based on the development of a workable concept for companies, a small empirical study was carried out, which can be used to numerically measure the sustainability performance of companies. Two utility analyses were completed. One of them was supplemented by expert interviews. Well-known practitioners from the business world were interviewed and asked for their assessment of ecological performance indicators. The result of the research is an indicator-based concept that can be applied in corporate practice to determine ecological sustainability performance.
\end{abstract}

\section{KEYWORDS}

Ecological and Social Sustainability, EU Regulations, Corporate Responsibility, Key Performance Indicators, Structured Digital Approach

\section{INTRODUCTION}

This paper shows the main reasons why companies should urgently measure their sustainability performance using key performance indicators. Due to this demand, a structured digital approach was developed within the scope of the empirical study which is supposed to support companies exactly at this point. With this structured digital approach, especially the ecological sustainability of companies can be recorded and evaluated in a number-based way.

This article will have the following structure. Starting with the origin of the term sustainability and its incorporation into the economy will be explained to highlight the motivation and importance of this topic for companies. Subsequently, more profound reasons for the sustainable entrepreneurial orientation will be given. Following this, previous approaches to implementing environmental sustainability in business are highlighted, which are used as the basis for the research. Next, the research gap identified is emphasised and the research method used to fill the gap is described. After that, the results of the research, i.e., the key figures and the dashboard including the structure of the dashboard are shown. Finally, an outlook into the future and the applicability of this concept in business is given. 


\section{ORIGIN OF THE TERM SUSTAINABILITY AND INCORPORATION INTO THE ECONOMY}

The word sustainability is one of the most discussed words in recent years and still is. Ultimately, however, no one, not even the companies, know exactly what this word means and what is hidden behind it [1]. Nevertheless, today attempts are made to label every consumer product, be it clothing, vehicles, financial investments or food, as "sustainable". Sustainability has now mutated into an omni-present seal of quality that tries to suggest to the user a consumption free of guilt [2]. It is visible that stakeholders of companies demand sustainable action, either through laws of politics or through the increasing demand for "green" products [3].

In the corporate environment and today's globalization, it quickly becomes clear that in the production processes of the products, ecologically sustainable action by the focal companies is not sufficient, but the worldwide supply networks in the direction of raw material suppliers must be considered. Significant changes can already be observed, especially between the focal company and their 1st-tier suppliers, in the focal company check the ecological sus-tainability of the 1st-tier suppliers and, if necessary, no longer approve them for tenders. As can be seen in Figure 1, the pressure for sustainability is being passed on from the end customer/ end producer to the raw material suppliers.

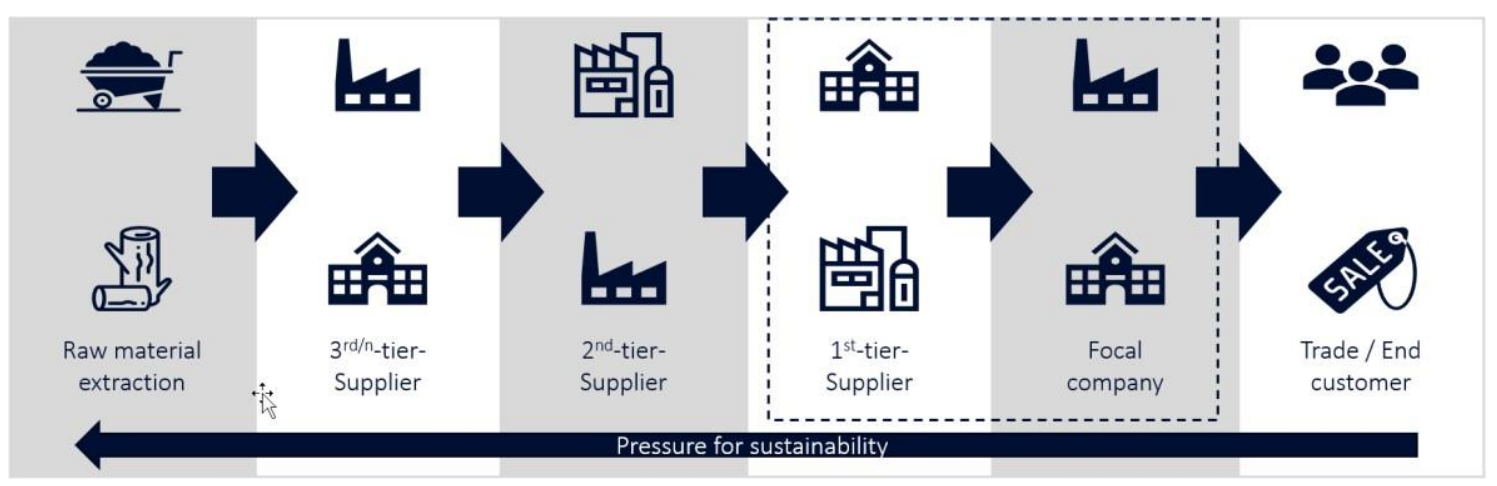

Figure 1. Supply network with pressure for sustainability

The origin of the term "sustainability" can be found in the 18th century in forestry. According to Carl von Carlowitz, the head of Freiberg, only as many trees should be felled in a forest as can grow back naturally within a certain period. The aim is to preserve the basic functions of a regenerative and natural system imperishably. This laid the foundation of the ecologically sustainable understanding. [4]

In 2015, the United Nations enacted the 2030 Agenda. This agenda contains 17 goals around the topics of people, planet, prosperity, peace and partnership [5]. In December of the same year, 195 countries signed a legally binding global climate protection agreement at the Paris Climate Change Conference. The long-term goal is to increase the global temperature by a maximum of 2 degrees Celsius compared to pre-industrial levels. [6]

The obligation for German companies, among others, to align themselves sustainably and to report on this arose in 2017 from the EU-CSR Directive 2014/95/EU. As a result, European capital market-oriented companies and their equivalent limited liability partnerships and cooperatives are obliged to expand their management report to include a statement of their non- 
financial activities in accordance with Section 289b of the German Commercial Code (HGB) if they meet the requirements of Section 267 (3) Sentence 1 of the German Commercial Code (HGB), are capital market-oriented or have an annual average of more than 500 employees. Section 267 (3) sentence 1 requires companies to make a non-financial statement if they exceed two of the following three criteria, namely if their balance sheet total exceeds $€ 20,000,000$, their sales revenue exceeds $€ 40,000,000$ and they employ more than 250 people. These non-financial activities can be topics such as environmental protection, employee protection, respect for human rights or avoidance of corruption and bribery. [7]

The EU Green Deal was adopted in December 2019. The goal is to make the EU greenhouse gas neutral by 2050 and to decouple economic growth from resource use [8]. As a result of the German Climate Protection Act 2020, the previous CO2 pricing for the energy sector and energyintensive industry will be supplemented by the areas of transport and buildings from 2021 . With a fixed price system, the cost of allowances will gradually increase from the year 2021 with 25 euros per ton of $\mathrm{CO} 2$ to the year 2026 to 55-65 euros per ton of CO2. [9] Consumers feel this $\mathrm{CO} 2$ pricing, for example, through increased gasoline prices.

Increasing competitive pressure as well as globalization and the resulting drop in production costs are forcing companies to focus primarily on their own core competencies. Non-value- adding activities are therefore increasingly being outsourced to external third parties. As a result, the depth of value creation in individual companies is decreasing and responsibility must be passed on to suppliers. In this construct, not only quality, delivery time and costs must be closely coordinated, sustainable behaviour must also be managed. [10]

\section{REASONS FOR THE SUSTAINABLE ENTREPRENEURIAL ORIENTATION}

In addition to legal obligations, there are essentially three reasons for anchoring a holistic sustainable corporate orientation in all corporate activities:

- Companies are generally set up for an indefinite period of time and are intent on offering customers the greatest possible benefits. Incorporating the holistic sustainable approach into the management and preparation of decisions improves and increases the acceptance and credibility of corporate commitment to society. [11]

- Companies are a part of society and should also integrate themselves into society by meeting the requirements of their stakeholders [12]. "They live from and in this society." [13] Stakeholders can be shareholders, employees, suppliers, government, site communities, customers, media, public, NGO's, politics, legal regulations and many more.

- Companies can save money and generate a competitive advantage through sustainable behaviour. In the meantime, many companies have already recognized that there is a lot of cost reduction potential in value chains. This includes, among other things, optimized processes, efficiently used resources and the reduction of waste. Not only these cost advantages, but also firm customer loyalty through sustainable products generates a unique selling proposition for companies and, at best, leads to a competitive advantage. [14]

Our economic system is currently in an ever faster spiral of optimization potential [15]. By restructuring the system, it is now possible to improve all three variables of the magic triangle: costs, time and quality at the same time [16]. Since then, the operational goals of the company have been steady growth, shorter product life cycles and the highest possible standardization with partial differentiation of the products. It is questionable how long this spiral will continue to turn in this direction and whether new optimization potential can be permanently discovered. 
[17] Or whether other parameters, such as sustainability, will drive the spiral in the future and expand the magic triangle into a magic square. In this regard, many are certain that everyone will benefit from the concept of sustainable business. Business itself, its shareholders, society

and the environment. The companies that can convince through a three-dimensional sustainability of their company and their products and can outperform the competition will be able to secure social acceptance and sales as well as long-term continuity and success in the long term. [18]

\section{IMPLEMENTATION OF ENVIRONMENTAL SUSTAINABILITY IN COMPANIES}

The pursuit of long-term continuity and success shows that environmental sustainability will be indispensable for companies in the future and is struggling for transparency, measurability and comparability. Up to now, companies have reported mainly on a verbal level in text form in a very subjective way. One way to increase measurability and transparency is to determine ecological indicators.

There are already various concepts and guidelines that support companies on their way to sustainable action and make ecological performance partially measurable. These include the UN Global Compact, the GRI Standards, the Sustainable Development Goals, the OECD Guidelines, the German Sustainability Code, DIN ISO 26000, DIN ISO 14001 and DIN ISO 14031, and the EMAS EU Eco-Audit. These concepts only partially contain key figures for measuring environmental sustainability.

The Global Compact is the world's largest sustainable business initiative, with more than 8,000 companies and 4,000 non-commercial organizations in over 160 countries participating. [19] It does not provide companies with environmental metrics but does reference the GRI standards [20]. The globally recognized Global Reporting Initiatives standards (GRI) were published in 1997 and are guidelines to assist organizations in reporting economic, environmental, and social impacts. They comprise a very detailed and well-structured collection of indicators for the various sustainability topics. [21] The United Nations adopted the Sustainable Development Goals (SDGs) as part of the 2030 Agenda in 2015. The SDGs include 17 globally valid goals for sustainable development with 169 sub-goals, for which a great number of key figures are available [22]. The Organisation for Economic Co-operation and Development (OECD) is an international organization that works for better policies and better lives for people [23]. The total of 10 thematic areas of the OECD Guidelines with 67 targets do not include any indicators. The German Sustainability Code (DNK) is an internationally recognized reporting standard that was developed and tested by the German Council for Sustainability in cooperation with the business community based on voluntary international reporting standards. Sustainability is defined here as a joint effort that pays off for everyone. For sustainability it is a matter of economic reason, ecological necessity and social self-image. [24] The German Institute for Standardization (DIN) and International Organization for Standardization (ISO) adopted Standard 26000 in 2010 [25]. The aim is to create a common and international understanding of responsible organizational management based on shared values, principles and rules. DIN ISO 26000 is not certifiable because it does not contain any directly controllable and comparable criteria such as key figures. [26] DIN ISO 14001 has the task of helping organizations to implement a comprehensive environmental management system. In principle, DIN ISO 14001 can be certified by an external organization [27]. For this, organizations must monitor, measure, analyse and evaluate their environmental performance [28]. To support organizations in their corporate performance evaluation, DIN ISO 14031 Environmental management - Environmental performance evaluation - Guidelines was developed, which serves as a mutually complementary tool to DIN ISO 14001 
[29]. The Eco-Management and Audit Scheme (EMAS certificate) is a domestic and nonEuropean voluntary award available to any organization from any sector of the economy with the will to assume responsibility towards the economy and the environment, improve its own environmental performance and strengthen communication with interested stakeholders [30].

\section{RESEARCH GAP AND METHODOLOGY OF GAP FILLING RESEARCH}

The current situation in the German economy is that some companies are obliged to consider the environment and must also report this annually. The available support based on the described concepts and guidelines still leaves the companies partly floating in the air. The basic attitude of sustainable business orientation is still very young and must be linked with existing procedures and experiences to lead entrepreneurs to new topics. The first step into sustainability usually equals a verbal description of actions, which are thus difficult for stakeholders to understand. Corporate managers have always been used to managing companies with the help of figures, data and facts. Now the challenge is to integrate the new topic of environmental sustainability into existing corporate processes and controlling systems. Only then the consideration for our environment will be successfully integrated into corporate processes in the long term.

This empirical study addresses this research gap. Environmental sustainability must be made measurable and accessible to companies. As research method, two utility analyses and therein integrated guided interviews with subject matter experts were conducted, as shown in Figure 2 in the blue-coloured paths.

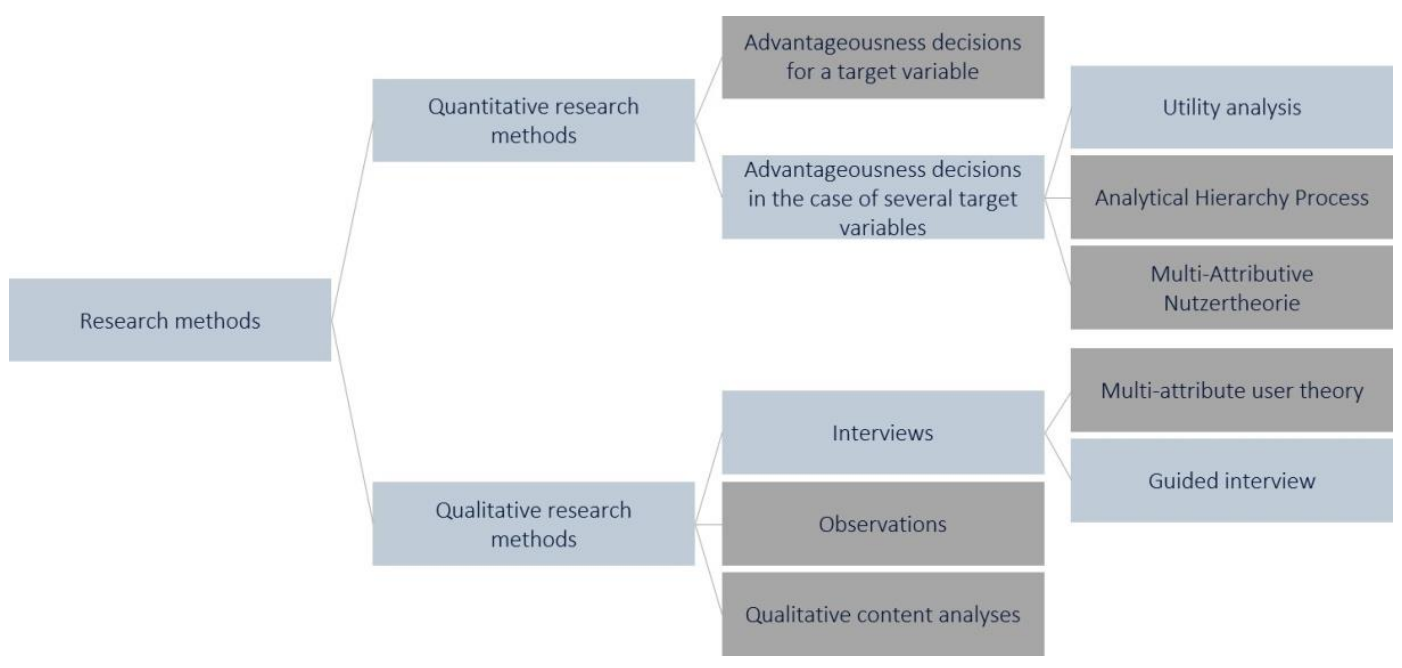

Figure 2. Selection of the research method

Utility analyses are used if there are a large number of aspects to be considered in a decision. However, the aspects cannot be ranked arbitrarily according to their relevance. Utility analyses are also used if several people are participating in a decision. These persons may have different experiences which they can contribute, but which do not necessarily lead to a meaningful result.

[31] In this specific case, some ecological parameters were evaluated by several experts. The process of utility value analyses begins with the determination of target criteria and target criteria weighting and is followed by the evaluation of alternatives. Afterwards, the utility values are determined, and the advantageousness is assessed. [32] 
The guideline-based interviews were included in the utility analyses and refer to questions with the aim of questioning existing assumptions or prior considerations [33]. In the context of this research, seven subject matter experts were interviewed, all of whom have a very successful career path, such as managing directors or managing consultants in the field of automotive industry. The experts evaluated ten ecological indicators based on ten criteria. Subsequently, an interview was conducted with each expert to understand the evaluations and to ask further questions of understanding.

\section{Results of the Research (Key Performance Indicators and DASHBOARD)}

The ten environmental indicators examined with the help of the utility value analyses and the subject matter experts are assigned to six categories. These include the categories energy, emissions, materials, waste, water and environmental assessment of suppliers, service pro- viders and the supply chain. The environmental indicators were measured against the following criteria on a scale of one to six according to the German school grading system: Data collection/ data availability, influenceability/ coverage, interpretability, data accuracy/ granularity, quantifiability/ practical measurability, time effort, financial effort, comparability, significance for relevant stakeholders, significance for corporate objectives.

The cumulative result of the research based on the utility analyses and expert interviews resulted in a ranking of the ten ecological indicators:

1. total energy consumption in the company from renewable/ non-renewable sources (energy category).

2. weight of hazardous/ non-hazardous waste broken down by: Reuse, recycling, composting, recovery, waste incineration, saline wastewater injection, landfill, on-site storage, other (waste category)

3. quantity of renewable/ non-renewable materials used by weight or volume (materials category)

4. total water withdrawal/ return to surface water, groundwater, seawater, produced water, third- party water (water category)

5. gross volume of indirect energy related GHG emissions (scope 2) including $\mathrm{CO}$, $\mathrm{CH} 4$, $\mathrm{N} 2 \mathrm{O}, \mathrm{HFC}, \mathrm{PKFW}, \mathrm{SF} 6, \mathrm{NF} 3$ (emissions category)

6. gross volume of direct GHG emissions (scope 1) including $\mathrm{CO} 2, \mathrm{CH} 4, \mathrm{~N} 2 \mathrm{O}, \mathrm{HFC}, \mathrm{PKFW}$, SF6, NF3 (category emissions)

7. percentage of recycled feedstock used (materials category)

8. number of suppliers identified as having significant actual and potential negative environmental impacts (category environmental assessment of suppliers, service providers, and supply chain)

9. percentage of existing and new suppliers that have been screened for environmental criteria (category environmental assessment of suppliers, service providers as well as supply chain)

Gross volume of other indirect GHG emissions (Scope 3) including CO2, CH4, N2O, HFC, PKFW, SF6, NF3 (category emissions).

The ecological indicator 'Gross volume of other indirect GHG emissions (Scope 3) including $\mathrm{CO} 2, \mathrm{CH} 4, \mathrm{~N} 2 \mathrm{O}, \mathrm{HFC}, \mathrm{PKFW}, \mathrm{SF} 6, \mathrm{NF} 3$ ' is not included in the ranking, as it was not considered measurable and targetable by the experts. 
The energy category was rated best overall, which means that it is easiest to collect key figures on energy. The total energy consumption of companies is easy to determine. Based on meter clocks or invoices and with the corresponding electricity mix, this breakdown by individual energy sources is easily possible. Nevertheless, a shockingly number of companies do not know how much energy is consumed in which building or which technical equipment requires how much energy.

The category of emissions has been assessed on average. In general, it is difficult to determine emissions precisely, since GHG emissions cannot be measured but must be calculated. Basically, GHG emissions can be divided into three areas according to the GHG Protocol, the so-called Scope 1, 2 and 3, as they were also listed and evaluated in the utility analysis each as a separate indicator.

Scope 1 includes all direct emissions generated within the company itself. This includes the company facilities and its own vehicle fleet. Scope 2 includes all indirect emissions from purchased electricity, gas, heating and cooling. Scope 3 considers all indirect emissions from upstream and downstream stages of the business. Toward the downstream, these include purchased goods and services, capital equipment, fuel and energy, distribution, waste, travel, employee transportation and assets. In the upstream direction, emissions from transport and distribution, processing of sold products, use by sold products, product disposal, assets, franchises and investments belong to Scope 3 [34].

The category of used materials cannot be evaluated in summary. According to the experts, the breakdown of materials into renewable and non-renewable materials can be easily understood. The separation between renewable and non-renewable materials as such can be understood by the purchasing department. Identifying the percentage of materials used from recycled feedstocks, on the other hand, is much more complex. In the case of purchased semi-finished parts or components, for example, this information is only possible if the information on renewable and non-renewable materials and the percentage of recycled starting materials along the upstream supply network is known. For companies in the manufacturing sector that have no influence on the proportion of renewable and non-renewable materials, it may be useful to distinguish between recyclable and non-recyclable materials.

The second highest score in the utility analysis is for waste. The breakdown of waste types, such as reuse, recycling, composting, etc., is relatively easy to track based on waste separation and evidence of disposal costs. In addition, purchasing departments know which materials are used and their properties.

Water, considered separately according to water extraction and water recycling, ranks in the upper half of the evaluation. The basic water withdrawal can be read based on invoices and water meters. However, the breakdown between the different types of water source, such as surface water, groundwater or third-party water needs to be looked a little more closely.

The environmental rating of suppliers, service providers as well as the supply chain was rated very poorly by the seven experts and placed second to last in the ranking. In principle, it is possible to obtain information from suppliers, but it involves a great deal of effort. Only by building up enormous pressure the data collection from 1st-tier suppliers is possible. Thus, tracing along the supplier networks is still very difficult today. The only way to get information is through annual audits of the suppliers.

The overall result of the utility value analysis and the experts justifications clearly show which topics of ecology can be measured more easily and better with the help of ecological indicators 
and which cannot. This assessment formed the basis for the selection of ecological indicators for the developed concept with indicator list. In principle, however, it must be mentioned that ecological sustainability encompasses other subject areas and that these must not be neglected.

\section{STRuCTURE OF THE CONCEPT}

The structure of the fully developed approach can be seen below in Figure 3. This structure with the integrated ecological key figures can be used and completed individually for each company. With application in regular time intervals, both improvements and deterioration of the environmental performance in the individual subject areas can be recognized.

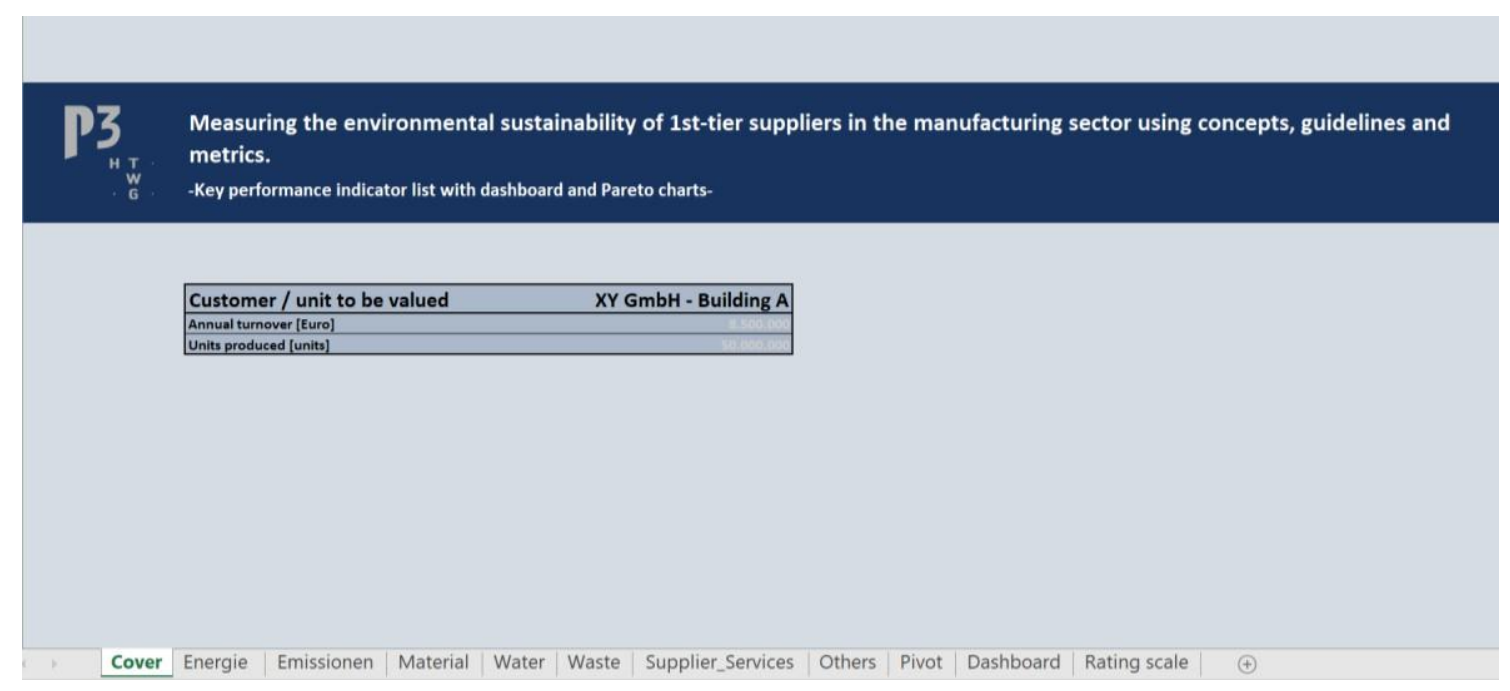

Figure 3. Structure of the concept with list of key figures

Each ecological topic such as energy, emissions, materials, water, waste, suppliers, service providers and other topics form a separate area. This structure serves to keep track of all topics in the ecology dimension and to reduce the complexity of the dimension. Within each category, individual parameters of ecological sustainability are recorded numerically and subsequently the key figures are determined. To explain the procedure in detail, the example of energy is used here, whereby the procedure is the same for each dimension. 


\begin{tabular}{|c|c|c|c|c|}
\hline$D \int^{\stackrel{T}{W}} \underset{G}{T}$ & \multicolumn{4}{|c|}{$\begin{array}{l}\text { Measuring the environmental sustainability of 1st-tier suppliers in the manufacturing sector using concepts, guidelines } \\
\text { and metrics. } \\
\text {-Key performance indicator list with dashboard and Pareto charts- }\end{array}$} \\
\hline \multicolumn{5}{|l|}{ Energy } \\
\hline Business Unit & Energy source & Origin of the energy source & Corporate Infrastructure & Energy consumer \\
\hline Production area & Biomass (electricity) & Renewable energy source & Technical equipment & Machines of production \\
\hline Production area & Biomass (electricity) & Renewable energy source & Technical equipment & Compressor \\
\hline Production area & Biomass (electricity) & Renewable energy source & Heating & Heating system \\
\hline Production area & Biomass (electricity) & Renewable energy source & Cooling & \begin{tabular}{|l|} 
Air conditioning \\
\end{tabular} \\
\hline Production area & Biomass (electricity) & Renewable energy source & Ventilation & Ventilation system \\
\hline Production area & Biomass (electricity) & Renewable energy source & Cleanroom & Filter system \\
\hline Production area & Biomass (electricity) & Renewable energy source & Compressed air & Plant internal e.g. pneumatic of the machine \\
\hline Production area & Biomass (electricity) & Renewable energy source & Compressed air & Plant external e.g. pneumatic gun \\
\hline Production area & Biomass (electricity) & Renewable energy source & Light & Light bulbs \\
\hline Production area & Biomass (electricity) & Renewable energy source & Own logistic intern & Electric forklifts \\
\hline Production area & Biomass (electricity) & Renewable energy source & Own logistic intern & Electric hoists \\
\hline Production area & Biomass (electricity) & Renewable energy source & Own logistic intern & Electric pallet trucks \\
\hline Production area & Biomass (electricity) & Renewable energy source & Own logistic intern & Autonomously driving logistics robots \\
\hline Production area & Biomass (electricity) & Renewable energy source & Own logistic intern & Conveyor belts \\
\hline Production area & Biomass (electricity) & Renewable energy source & \begin{tabular}{|l|} 
Electrical production monitoring \\
\end{tabular} & \begin{tabular}{|l|} 
RFID technology \\
\end{tabular} \\
\hline Production area & Biomass (electricity) & Renewable energy source & Electrical production monitoring & Computers and monitors \\
\hline Production area & Biomass (electricity) & Renewable energy source & Finished parts warehouse & Cooling \\
\hline Production area & Biomass (electricity) & Renewable energy source & Finished parts warehouse & Hand scanners / tablets / computers \\
\hline Production area & Biomass (electricity) & \begin{tabular}{|l|} 
Renewable energy source \\
\end{tabular} & \begin{tabular}{|l|} 
Finished parts warehouse \\
\end{tabular} & |Electrified high bay technology \\
\hline
\end{tabular}

Figure 4. Detailed view of the Energy category - Basic data

In the energy dimension, the goal is to identify and evaluate all energy consumers of a company. As can be seen in Figure 4, the company is divided into different business units, such as the production area and the administrative area to reduce complexity. Subsequently, the energy source is differentiated between biomass, cogeneration, oil, natural gas, oil, district heating, liquefied petroleum gas, geothermal energy, nuclear energy, coal, photovoltaics, solar energy, hydropower, wind power and others, with each energy source being assigned to the categories renewable energy or non-renewable energy. Consequently, the operational infrastructure is listed, which in turn is supplied with the energy consumers.

\begin{tabular}{|c|c|c|c|c|c|c|c|c|}
\hline Data source & $\begin{array}{c}\text { Energy } \\
\text { consumption } \\
{\left[\begin{array}{c}\text { [= absolute key } \\
\text { figure }]\end{array}\right.}\end{array}$ & $\begin{array}{l}\text { Unit } \\
\text { absolute } \\
\text { key figure }\end{array}$ & $\begin{array}{l}\text { Reference } \\
\text { value }\end{array}$ & $\begin{array}{l}\text { Unit reference } \\
\text { size }\end{array}$ & $\begin{array}{c}\text { Energy } \\
\text { consumption per } \\
\text { thousand euros of } \\
\text { sales } \\
\text { [=relative key } \\
\text { figure] }\end{array}$ & $\begin{array}{l}\text { Unit relative } \\
\text { key figure }\end{array}$ & $\begin{array}{c}\text { Evaluation of } \\
\text { the energy } \\
\text { carrier } \\
{[1-6]}\end{array}$ & $\begin{array}{c}\text { Evaluation of energy } \\
\text { consumption. } \\
{[1-6]}\end{array}$ \\
\hline Measurements / Calculation & 1000000 & kWh per year & 8.500 .000 & Euro annual turnover & 417,65 & KWh per TEuro sales & 3 & 4 \\
\hline Measurements / Calculation & 40000 & kWh per year & 8.500 .000 & Euro annual turnover & 4,71 & kWh per TEuro sales & 3 & 6 \\
\hline Measurements / Calculation & 2000 & kWh per year & 8.500 .000 & Euro annual turnover & 0,12 & kWh per TEuro sales & 3 & 1 \\
\hline Measurements / Calculation & 0 & kWh per year & 8.500 .000 & Euro annual turnover & 0,00 & kWh per TEuro sales & 3 & 0 \\
\hline Measurements / Calculation & 2500 & kWh per year & 8.500 .000 & Euro annual turnover & 029 & kWh per TEuro sales & 3 & 3 \\
\hline Measurements / Calculation & 0 & kWh per year & 8.500 .000 & Euro annual turnover & 0,00 & kWh per TEuro sales & 3 & 0 \\
\hline Measurements / Calculation & 50000 & kWh per year & 8.500 .000 & Euro annual turnover & 706 & kWh per TEuro sales & 3 & 5 \\
\hline Measurements / Calculation & 0 & kWh per year & 8.500 .000 & Euro annual turnover & 0,00 & kWh per TEuro sales & 3 & 0 \\
\hline Measurements / Calculation & 300 & kWh per year & 8.500 .000 & Euro annual turnover & 0,04 & kWh per TEuro sales & 3 & 3 \\
\hline Measurements / Calculation & 2250 & kWh per year & 8.500 .000 & Euro annual turnover & 0,15 & kWh per TEuro sales & 3 & 1 \\
\hline Measurements / Calculation & 0 & kWh per year & 8.500 .000 & Euro annual turnover & 0,00 & kWh per TEuro sales & 3 & 0 \\
\hline Measurements / Colculation & 0 & kWh per year & 8.500 .000 & Euro annual turnover & 0,00 & kWh per TEuro sales & 3 & 0 \\
\hline Measurements / Calculation & 5000 & kWh per year & 8.500 .000 & Euro annual turnover & 0,59 & kWh per TEuro sales & 3 & 2 \\
\hline Measurements / Calculation & 0 & kWh per year & 8.500 .000 & Euro annual turnover & 0,00 & kWh per TEuro sales & 3 & 0 \\
\hline Measurements / Calculation & 0 & kWh per year & 8.500 .000 & Euro annual turnover & 0,00 & kWh per TEuro sales & 3 & 0 \\
\hline Measurements / Calculation & 850 & kWh per year & 8.500 .000 & Euro annual turnover & 0,10 & kWh per TEuro sales & 3 & 3 \\
\hline Measurements / Calculation & 0 & kWh per year & 8.500 .000 & Euro annual turnover & 0,00 & kWh per TEuro sales & 3 & 0 \\
\hline Measurements / Calculation & 200 & kWh per year & 8.500 .000 & Euro annual turnover & 0,02 & kWh per TEuro sales & 3 & 4 \\
\hline Measurements / Calculation & 0 & kWh per year & 8.500 .000 & Euro annual turnover & 0,00 & kWh per TEuro sales & 3 & 0 \\
\hline
\end{tabular}

Figure 5. Detailed view of the Energy category - Determination of the energy consumption 
Figure 5 shows the next step, where the actual energy consumption is determined for each energy consumer by calculation, individual measurement, receipts, vehicle mileage and other references. Each number is assigned a corresponding unit. Consequently, energy consumption is referenced using annual sales in euros and sales in thousands of euros to create comparability. Subsequently, an individual evaluation is made by $\mathrm{P} 3$ automotive $\mathrm{GmbH}$. Based on empirical values, both, the energy consumer and the relative energy consumption per thousand euros are evaluated on a school grade scale from 1 to 6 . Here, 1 is the best rating and 6 the worst.

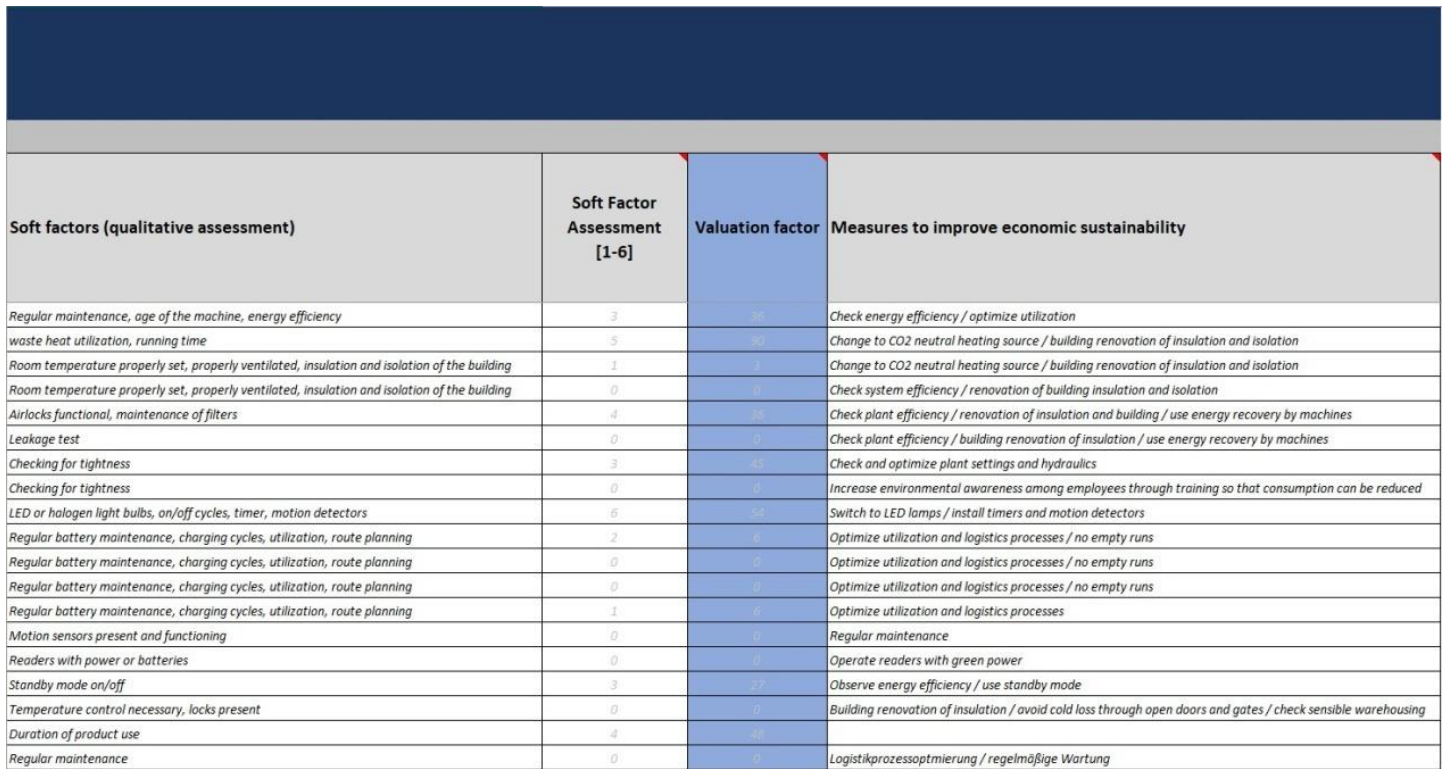

Figure 6. Detailed view of the Energy category - Soft factors and recommendations for improvement

In the area of sustainability, the soft factors should not be completely disregarded and can have a significant influence here in the collection of key figures as it's shown in Figure 6. Thus, an

extra field is available for each energy source to take other factors into account. For example, the age or regular maintenance of mechanical production facilities can be decisive. These soft factors are also evaluated using the school scale from 1 to 6 . Finally, the three ratings (energy source, relative energy consumption and soft factors) are added together. This is the basis for the creation of a Pareto diagram and for suggestions for improvement. The Pareto diagrams per dimension can be found in the dashboard of the approach.

This scheme is applied to each category as mentioned. The results of the individual categories are summarized in the dashboard. With the dashboard, the most important environmental key figures can be clearly presented to the management and investors and be used as motivation to initiate measures to improve environmental performance. In this way, the leap from information key figures to management key figures can be made and environmental goals can be linked to corporate goals.

\section{REVIEW, APPLICATION IN BUSINESS AND OUTLOOK}

The structured digital approach including key performance indicators developed and explained in this article is already very mature and practical. Nevertheless, on the scientific side of the research, there are still one or two opportunities for improvement. At best, the dimensions should be subjected to further validation with the help of case studies, for example. In addition, the 
linkage between the different dimensions could be strengthened. This tool forms an excellent basis for further development and improvement in the field of scientific work.

However, increasing pressure from stakeholders, especially national and international legislation and society, is leading to more and more pressure for sustainable business practices. This pressure for better environmental sustainability of the companies is directly passed on to the 1sttier suppliers in the supply network, in the opposite direction to the supply direction. The 1st-tier suppliers are thus forced to review their own business and communicate environmental sustainability.

Environmental sustainability is an indispensable part of our current age. Natural disasters and extreme weather stresses are taking a toll on the world's population. If we cannot keep within the 2 -degree limit of global warming by 2050 , these phenomena will increase significantly. People will continue to lose their homes along the coasts, and whole swaths of land could be flooded. On the other hand, we will be faced with countless climate refugees from regions close to the equator. These threats clearly show that each one of our world's population, especially companies, must begin to act. In doing so, the developed tool offers the possibility to create numbers, data and facts.

Due to the high potential of this approach in relation to further legal regulations in Germany and the EU, it will be pushed further by the developed individuals. This excel-based tool will be digitalized by $\mathrm{P} 3$ automotive $\mathrm{GmbH}$ in the following step. Then it will be possible to link the ecological key figures with further economic key figures in the producing sector, such as the production output and OEE. In addition, the perspective will be expanded from the manufacturing sector to the entire supply chain, for example regarding the German Supply Chain Act, which was passed in June 2021.

This in turn supports decision-making in companies. In conclusion, it remains to be said that while ecology is an increasingly important topic in the corporate environment, the dimension of economics will probably always remain the leading issue. Only in conjunction with economic efficiency and value creation will ecology find its way into the corporate world. This can be demonstrated with the key figures. Especially in the current situation of the economic downturn and the Covid 19 pandemic, companies are forced not to lose their profitability to secure jobs.

\section{REFERENCES}

[1] Bretzke, Wolf-Rüdiger (2014) „Nachhaltige Logistik. Zukunftsfähige Netzwerk- und Prozessmodelle“, Vol. 3, Berlin: Springer Vieweg, p1.

[2] Fox, Rüdiger (2019) „Nachhaltiges Management.“ Nachhaltigkeit als exzellenten Managementansatz entwickeln. Berlin, Heidelberg: Springer Berlin Heidelberg, p23.

[3] Umweltbundesamt (Editor.) (2020a) "Grüne Produkte: Marktzahlen. " Available online at https://www.umweltbundesamt.de/daten/private-haushalte-konsum/konsum-produkte/grueneprodukte-marktzahlen\#umsatz-mit-grunen-produkten, last check at 14.10.2020.

[4] Pufé, Iris (2014) „Was ist Nachhaltigkeit? Dimensionen und Chancen.“ Bundeszentrale für politische Bildung. Available online at https://www.bpb.de/apuz/188663/was-ist-nachhaltigkeit- dimensionenund-chancen, last check at 06.04.2020.

[5] United Nations (Editor) (w.y. (b)) "TRANSFORMING OUR WORLD: THE 2030 AGENDA FOR SUSTAINABLE DEVELOPMENT. A/RES/70/1." Available online at https://sustainabledevelopment.un.org/content/documents/21252030\%20Agenda\%20for\%20Sust ainable\%20Development\%20web.pdf, last check at 07.04.2020.

[6] Europäische Komission (w.y.) „Pariser Übereinkommen.“ Available online at https://ec.europa.eu/clima/policies/international/negotiations/paris_de, last check at 14.04.2020. 
[7] Hilbert, Stefan (2019) „Nachhaltiges Management.“ Nachhaltigkeit als exzellenten Managementansatz entwickeln. Berlin, Heidelberg: Springer Berlin Heidelberg, p521. Bundesamt für Justiz: Handelsgesetzbuch. HGB. Available online at https://www.gesetze-im- internet.de/hgb/ 289b.html, last check at 15.04.2020. Bundesamt für Justiz: Handelsgesetzbuch. HGB. Available online at https://www.gesetze-im- internet.de/hgb/ 267.html, last check at 15.04.2020.

[8] Die Bundesregierung (Editor) (2019) „CO2-Bepreisung.“ Available online at https://www.bundesregierung.de/breg-de/themen/klimaschutz/co2-bepreisung-1673008, last check at 27.07.2020.

[9] Die Bundesregierung (Editor) (2019) „CO2-Bepreisung.“ Available online at https://www.bundesregierung.de/breg-de/themen/klimaschutz/co2-bepreisung-1673008, last check at 27.07.2020.

[10] Ingo Gestring et al (2016) „Ethik im Mittelstand.“ Grundlagen und Instrumente zur praktischen Umsetzung. Wiesbaden: Springer Gabler, p. 216.

[11] Colsman, Bernhard (2016) „Nachhaltigkeitscontrolling.“ Strategien, Ziele, Umsetzung. Vol. 2. Wiesbaden: Springer Gabler, pp1-3.

[12] Colsman, Bernhard (2016) „Nachhaltigkeitscontrolling.“ Strategien, Ziele, Umsetzung. Vol. 2. Wiesbaden: Springer Gabler, p5.

[13] Colsman, Bernhard (2016) „Nachhaltigkeitscontrolling.“ Strategien, Ziele, Umsetzung. Vol. 2. Wiesbaden: Springer Gabler, p5.

[14] Marco Englert and Anabel Ternès (2019) „Nachhaltiges Management. Nachhaltigkeit als exzellenten Managementansatz entwickeln.“ Berlin, Heidelberg: Springer Berlin Heidelberg, pp61-62.

[15] Marco Englert and Anabel Ternès (2019) „Nachhaltiges Management. Nachhaltigkeit als exzellenten Managementansatz entwickeln.“ Berlin, Heidelberg: Springer Berlin Heidelberg, pp31-32.

[16] Gerboth, Thomas (2002) „Das magische Dreieck. Kosten-Zeit-Qualität“, p. 417. Available online at https://www.beck-elibrary.de/10.15358/0935-0381-2002-7-417/das-magische-dreieck- volume-142002-issue-7, last check at 21.04.2020, p417.

[17] Marco Englert and Anabel Ternès (2019) „Nachhaltiges Management. Nachhaltigkeit als exzellenten Managementansatz entwickeln.“ Berlin, Heidelberg: Springer Berlin Heidelberg, pp31-32.

[18] Jeurissen, Ronald (2000) „Book Reviews.“ John Elkington, Cannibals With Forks: The Triple Bottom Line of 21st Century Business. Capstone, Oxford, 1997, 402 pp. ISBN 1-900961-27-X. In: Journal of Business Ethics (23), p. 229-231, last check at 17.04.2020, pp. 229-331.

[19] United Nations (Editor) (2014) „Leitfaden für nachhaltiges Wirtschaften.“ Für eine nachhaltige Zukunft. New York. Available online at https://www.globalcompact.de/wAssets/docs/Nachhaltigkeits-CSR-Management/UNGC-Report20150930-German-FINAL.pdf, last check at 05.05.2020, p7.

[20] Blanco, Ana et al (2014) „Verbindungen schaffen: Nutzung der GRI G4 Leitlinien zur Berichterstattung über die Global Compact Prinzipien.“ Editor Geschäftsstelle Deutsches Global Compact Netzwerk (DGCN) und Deutsche Gesellschaft für Internationale Zusammenarbeit (GIZ) $\mathrm{GmbH}$. Available online

https://www.globalcompact.de/wAssets/docs/Reporting/verbindungen_schaffen-nutzung_der_GRI_G4_leitlinien_zur_berichterstattung_ueber_die_Global_Compact_Prinzipien.pdf , last check at 29.04.2020, pp7-8.

[21] Global Reporting Initiative (Editor) (2020) “About GRI." Available online at https://www.globalreporting.org/information/about-gri/Pages/default.aspx last check at 02.06.2020.

[22] GRI; UN Global Compact; WBCSD (Editor) (w.y.): „SDG Compass.“ Leitfaden für Unternehmensaktivitäten $\mathrm{zu}$ den SDGs. Available online at https://www.globalcompact.de/wAssets/docs/Sustainable-Development- Goals/Publikationen/SDGCompass/SDG-Compass_German.pdf, last check at 07.05.2020, p5.

[23] Organisation for Economic Co-operation and Development (2020 (a)) "Who we are." Available online at https://www.oecd.org/about/, last check at 26.05.2020.

[24] Rat für Nachhaltige Entwicklung (Editor) (2020) „Deutscher Nachhaltigkeitskodex.“ Maßstab für nachhaltiges Wirtschaften. Available online at https://www.deutscher- nachhaltigkeitskodex.de/deDE/Documents/PDFs/Sustainability- Code/RNE_DNK_BroschuereA5_2020.aspx, last check at 29.04.2020, p5.

[25] International Organization for Standardization (Editor) (2010) "Guidance on social responsibility." ISO 26000:2010(E). International Organization for Standardization. 
[26] Franz, Peter et al (2011) „Die DIN ISO 26000“ Leitfaden zur gesellschaftlichen Verantwortung von Organisationen - Ein Überblick -. Editor Bundesministeriums für Arbeit und Soziales. Available online at https://www.bmas.de/SharedDocs/Downloads/DE/PDF-Publikationen/a395- csr-din26000.pdf;jsessionid=80C59214AC11B528366BA40A3FAFEA29? blob=publicationFile \&v= 2, last check at 29.04.2020, pp8-9.

[27] International Organization for Standardization (Editor) (2015) "Environmental management systems — Requirements with guidance for use.” ISO 14001:2015, pVIII.

[28] International Organization for Standardization (Editor) (2015) "Environmental management systems - Requirements with guidance for use.” ISO 14001:2015, p14.

[29] International Organization for Standardization (Editor) (2013) „Umweltmanagement - Umweltleistungsbewertung - Leitlinien." ISO 14031:2013, p4.

[30] Amtsblatt der Europäischen Union (Editor) (2013) „BESCHLUSS DER KOMMISSION vom 4. März 2013. über ein Nutzerhandbuch mit den Schritten, die zur Teilnahme an EMAS nach der Verordnung (EG) Nr. 1221/2009 des Europäischen Parlaments und des Rates über die freiwillige Teilnahme von Organisationen an einem Gemeinschaftssystem für Umweltmanagement und Umweltbetriebsprüfung unternommen werden müssen“, p2.

[31] Kühnapfel, Jörg B. (2019) „Nutzwertanalysen in Marketing und Vertrieb.“ Vol.2. 2019. Wies- baden: Springer Fachmedien Wiesbaden, p3.

[32] Götze, Uwe (2014) „Investitionsrechnung.“ Modelle und Analysen zur Beurteilung von Investitionsvorhaben. Vol.7. Berlin: Springer Gabler (Springer-Lehrbuch), p193.

[33] Goldenstein, Jan; Hunoldt, Michael; Walgenbach, Peter (2018) „Wissenschaftliche(s) Arbeiten in den Wirtschaftswissenschaften." Themenfindung - Recherche - Konzeption - Methodik - Argumentation. Wiesbaden: Springer Gabler, p95.

[34] Greenhouse gas protocol. Corporate value chain (Scope 3) accounting and reporting standard: supplement to the GHG protocol corporate accounting and reporting standard (2011). [Washington, DC], [Geneva, Switzerland]: World Resources Institute; World Business Council for Sustainable Development. Available online at https:/ghgprotocol.org/sites/default/files/standards/CorporateValue-Chain-Accounting- Reporing-Standard_041613_2.pdf, last check at 23.07.2020, p5.

\section{AUTHORS}

Sabrina Stern finally completed her master's degree (M.A.) at the Hochschule für Technik, Wirtschaft und Gestaltung in Konstanz, Germany in cooperation with P3 automotive GmbH from Stuttgart, Germany. She investigated the measurability of the ecological sustainability of companies and developed a structured digital approach with integrated key figures. Now she is a management consultant in the areas of supply chain management and sustainability for clients in the automotive industry at P3 automotive GmbH, Stuttgart, Germany.

Sven Steck (MBE) is managing partner at P3 automotive GmbH in Stuttgart, Germany. He advises companies from all industries especially customers of the automotive industry on supply chain management and sustainability topics.

Prof. Dr. Stefan Waitzinger is professor in the Department of Economics at the Hochschule für Technik, Wirtschaft und Gestaltung in Konstanz, Germany. He teaches the topics of digitalization, value creation and optimization.
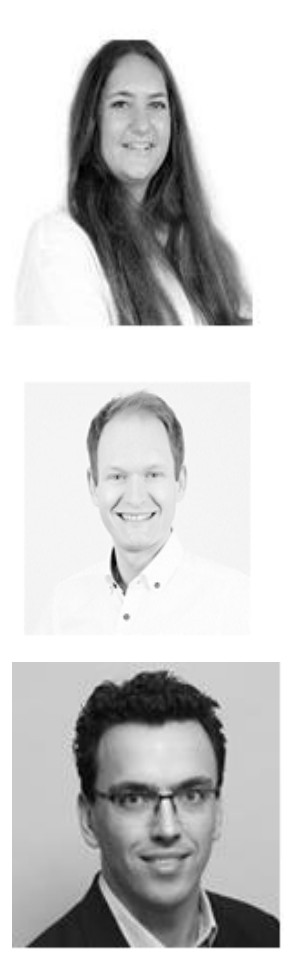